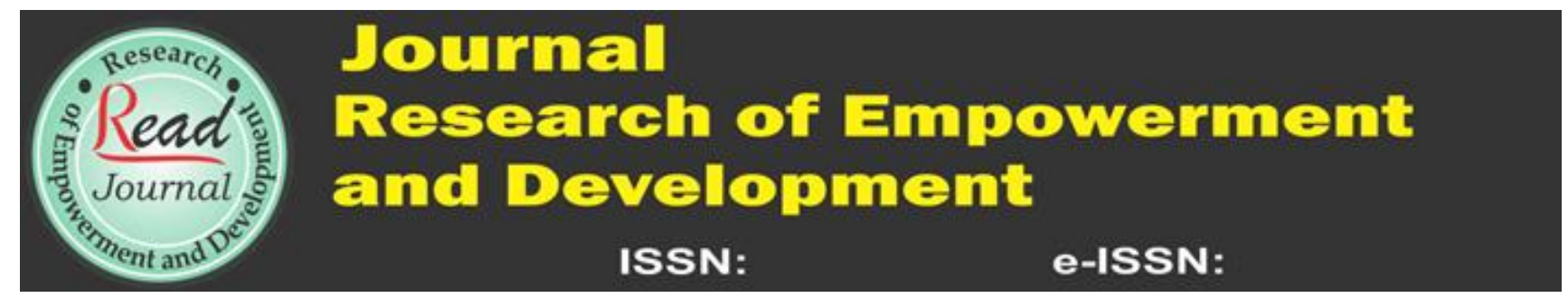

\title{
Online Activism Of Social Community In Handling Social Issues In The City Of Malang
}

\author{
Tia Subekti ${ }^{1}$, Irza Khurun'in ${ }^{2}$ \\ ${ }^{1}$ Governmental Science Program ${ }^{2}$ International Relations Program - FISIP Universitas Brawijaya \\ *Corresponding author. E-mail: tiasubekti@ub.ac.idirza.khurunin07@ub.ac.id²
}

Submited : July 2019, Accepted: January 2020, Published : March 2020

\section{HIGHLIGHT}

- Nowadays, social media is the social community's main strategy for activism.

- The formation of activism conducted by the social community in the City of Malang City aims to respond to social problem.

\section{Keyword}

Social community, social media, social networking, social problem, Malang City

\begin{abstract}
This paper aims to see the formation of social movements in Malang addressing social issues in Malang. Some of the movements that become the focus of this paper are the Malang Care Community or ASLI Malang and Social and Humanist Society in Malang. Interestingly, the communities are doing their activities online and using social media as the main instrument of movement. If in general online media basedcommunities are only informative, it is different with Malang. Here the communities perform real actions such as social activities. For examples: social aids for victims of natural disasters, street children, poor people who need help, and other problems. Last but not least is the emergence of free motorcycle-taxi riders that arose due to the protest of angkot (city transport) drivers toward online motorcycle taxi resulting in an angkot drivers' strike. The movement was able to collect motorcyclerider volunteers up to 700 motorcycles and 80 cars. The 4 days activity was the culmination of the social community awakening which arises in response to sociodynamic in society

The emergence of various social communities is the marker of the rise of civilian powers and the strengthening of non-state actors. The social community as a form of movement becomes an alternative for civil society to engage in social issues, rather than to join political organizations such as political parties or interest groups whose main interests are political interests. Charles Tilly (2004) defines social movements as an organized public collective effort to make certain claims to the intended authorities. Sidney Tarrow (2004) explains that social movements are generally born from social problems that lead to contentious. The orientation of social movements is to create a world order of social justice. Furthermore, in data collection, the authors conducted in-depth interviews, observations, and documentation. By using social movement perspective, the main argument in this paper is, first, social media is the social community's main strategy for activism. Second, the pattern of social movements that arise is departing from social concerns of civil society in the city of Malang in view of social issues. Third, the formation of activism conducted by the social community in the City of Malang City aims to respond to social problem
\end{abstract}

\section{Introduction}

According to data from Kompas (2017), monthly Facebook users or what it called monthly active users (MAU) reached 2 billion people. There is an increase of $17 \%$ annually. Meanwhile the number of daily active users (DAU) reached 1.23 billion person or an increase of $18 \%$ annually. Based on data reported by Kompas, in average, Facebook users use smartphones $\mathrm{t}$ o open his account. This is reinforced by the 
data showing the increase of mobile phone users at 23\% yearly (Bohang, 2017).

The data shows us that Facebook has become a necessity. Facebook becomes a medium of information as well as communication between communities. The presence of Facebook in the communities raises online communities. These communitie s utilize Facebook as a communication space between members. Osbarn and Neumeyer (1984: 59) define community as "a group of a people having in a contiguous geographic area, having common interests and activities centers, and functioning together in the chief concern of life". The definition suggests that the emergence of communities is due to at least three things; first: the people who are close together; second: common interest and interest; third: perform the same function for the common goal.

In the context of Malang, the number of social communities that have been active on Facebook is more than 60 communities. The communities range from citizens of Malang, trading, hobby basedcommunities, and so forth. The two communities in Malang that have been studied by the author are Asli Malang or Komunitas Peduli Malang (Malang Care Community) and SHC or Social and Humanist Community. The two communities use social media Facebook tools for networking and displaying activism. Their activities are varied from volunteering to help victims of disasters, raising donations for the less fortunate, to various other social activities. In the end, the emergence of mass media changes attitudes of members of society (Castell, 2010), accelerates the flow of information technology, especially social media, as it has given the comprehensive means for people to express their attitude, be it in the form of new social movements, or "watchdog" of the behaviour of officials or politicians (Dewantara and Derajat, 2015). Meanwhile, Giddens

(1993:642) defines social movement as collective effort to pursue common interests, or achieve common goals through collective action beyond established institutions.

Based on two online activism that the authors have been investigated, the biggest mass mobilization is the emergence of volunteers of motorcycle riders and car taxi drivers in Malang in responding to the angkot crisis when there was angkot strike protesting the presence of application based-motorcycle and car taxis in Malang. The volunteer movement then renamed themselves "Ice Tea Anget" (Hot Iced Tea). This research raises the question on how online activism formed in Malang City, particularly in the case of Ice Tea Anget movement.

\section{Research methods}

This study used qualitative approach to explain online activism by social community in Malang City and the establishment of Ice Teh Anget movement as the culmination of the movement. The qualitative approach places human beings as the main objects or everything that is influenced by human beings (Indranata, 2008). Qualitative approach is expected to rigidly describe data findings.

Furthermore, the methods to collect primary data were in-depth interviewing and observation by involving two social communities in Malang City. Meanwhile, to enrich the data, the authors conducted literature study to gain secondary data. The two communities that are the focus of this paper is Komunitas Peduli Malang (Asli Malang) or Malang Care Community and Social and Humanist Society (SHS). The selection of the two communities is based on activities they undertaken by them that are mostly in the social and educational fields. In addition, the two communities are among the proponents of the Ice Tea Anget movement in the City of Malang. Within the Ice Tea Anget, there were 700 motorcyclists and $80 \mathrm{car}$ drivers who volunteered as free motorcycle riders and car taxi drivers during the angkot strike in Malang.

The movement replaced government's role in public transportation in Malang during the 
strike. This is sufficient to confirm that public spaces in the form of social media have shaped political sphere and other strategic issues. The unit of analysis in this study is the social community in Malang City in doing its activation on the movement of Ice Tea Anget which utilize social media network Facebook as medium of media publication and mobilization of the period

\section{Result and Discussion}

\subsection{Social Community Activism In Malang: Social And Humanist Society (Sha) And Asli Malang \\ Dewantara and Widhyharto} (2015) explain that the emergence of social media as public space has become the watchdog of the behaviour of rulers. The community also expressed their opinions and fight for and seeking support through social media. The examples for this movements in social media, particularly Twitter, are \#saveAhok and \#saveKPK. Furthermore, Dewantara and Widhyharto (2015) explain that the phenomenon gave birth to digital native.
Community Care which has a membership of 381,000 members. In this study the authors take two communities as the focus, namely Social and Humanist Society (SHA) and Komunitas Peduli Malang (Asli Malang). SHS community and other social communities provide assistance to tackle the problems of poverty, street children and orphans. According to Ana, the founder of the SHS community, SHS has cooperated with several orphanage partners in around poorer highlands. Donations collected by SHS are alternately supplied to the orphanages. The SHS support is flexible, not only accepting fresh money but also receiving goods-shaped assistance such as clothing, used clothes, or home furnishings. Ana stated:

"We gave them a second hand refrigerator that is still worth to an orphanage and they were thrilled. In fact they also ask if there was rice cooker."

SHS uses Facebook as a primary means of networking and exchanging information. Fundraising also becomes easier if it is taken through Facebook. The

\section{members of society post news of natural disaster in Facebook account of Malang Care Comunity}

The mushrooming of social media community whose activities are mostly online is due to the following reasons: first, cost-effective because it can be done without face to face meeting. Second, communication is more intense because it can be online 24 hours. Third, members can easily be expanded since in digital world there is no space limitation. Fourth, the information can be delivered massively because it can be easily shared. In Malang, there are at least approximately $\quad 47 \quad$ social communities Facebook.

Based on the research, on average communities have members of at least 3000 members. The community that has the most members is Asli Malang or Malang

\section{unity move to provide assistance The assistance comes}

community shares about open donation in the mass media, then donors contact the community to distribute the assistance.

In its activities SHS often cooperate with the government and other communities such as Asli Malang and Info Malang Raya (IMR). One example is on October 22, 2017 SHS together with IMR and the government conduct home surgery on Jalan Panjaitan Gondanglegi Kulon Malang Regency. SHS and IMR started to initiate fundraising on September 26, 2017 (Sigap88news.com). Additonaly, SHS also provides volunteers for natural disaster and accidents. In taking part in dealing with the problem of natural disasters, social communities often conduct fundraising to provide assistance. The following is the 
working model of SHS and Komunitas Peduli Malang in handling natural disaster.

The similar procedure also applied in providing volunteer whenever traffic accidents occurred. Malang Care Community spread the full story with the location and time of the event and volunteers will come to provide assistance.

The advantage of online activity is information disseminated through social media more is quickly accepted by community members and quick to get responses. According to Bambang, the coordinator of Malang Care Community, members of the community will move quickly if there is a traffic accident. Community members are ready to volunteer to provide early help or bring victims to the hospital.

In the field of environment, both SHS and Community Care Malang often do cleaning activities of the city, i.e cleaning the garbage in the public square of Malang city after public events. Another environmental activity is "Kampoeng Putih" that is the painting of some villages in Malang City to look clean and neat. The community is also doing pavement holes in Malang.

In the field of education, SHS community develop community libraries in Malang Regency. Ana, as activist at the SHS, collect donations of books to fill out the library she built. The libraries are established to facilite the need of reading among children with limited access to books , especially in the district of Malang. Activity in the health sector is also undertaken by SHS and Asli Malang through fundraising for the underprivileged people who experience serious illness.

\subsection{The Movement Of Ice Teh Anget: From Social Community To Social Movement}

in Malang City, both offline and offline, not only influences social issues. The protests of angkot and conventional taxi drivers on the presence of application-based taxis (motorcycles and cars) is a moment when social community actors enter social movement sphere.

Social movement, according to Snow, Sarah, and Kriesi (2006), is a collective entity voicing complaints and concerns about rights and welfare in various types of collective actions which serve as vehicles to articulate the collective interests of civil society. Social movement emerges as a collective reaction to a system that is considered disturbing. Melucci (1996) defines social movements as one particular form of collective action that describes the orientation and other particular areas. In short, social movements can be interpreted by the following keywords, namely collective action; orientation of change as its purpose or claim; some are non-institutional collective action; with diverse organizational levels; and varying degrees of continuity. Social movement does not have to be continuous, but at some stage the social movement will disappear or change into an institutionalized organization.

Social movement in the 1960s had experienced a shift in which new social movement did not only consist of labours and peasants, but also groups of people who did not directly involve in production systems such as non-governmental organizations, students and communities (Situmorang, 2007). The main characteristic of new or modern social movement is not limited by the Marxist ideology as in the old social movements, its goal is non-material, diverse movement strategies and actors or movement participants are not limited by particular classes.

The emergence of the Ice Teh Anget is a public response to a protest carried by angkot drivers and conventional taxis that peaked at strike action on 6 to 9 March 2017. Hearing that there would be angkot strike, members of civil society of Malang who joined with the community took preventive step of public transportation congestion. 
Social opposition in society opens up a space for the social community to perform movement. It has been mentioned that the social movement is a social change orientedcollective action. Thus, it can be seen that the Ice Teh Anget Movement is a societal symbol for change in public transport. First, the government is considered to be less concerned about public transport. Second, horizontal conflicts that arise make people worried about social stability in society. Hence, the step taken was to make the movement of volunteer of motorcycle riders and car taxi drivers in lieu of public transport paralysed for four days.

The mobilization begins with ideas in online communities such as Asli Malang and SHS. The online network they organised had good responses from other communities as well as from the general public. At that moment, the mobilization was undertaken through Facebook and it was able to collect 700 motorcycle riders and 80 people car drivers. In coordinating the volunteers they formed an ad hoc committee.

Their strategy was using social media, in particular Facebook. Due to their massively and rapidly spread of information, the movement was immediately recognized by the wider community. The community or in this case mostly the primary, junior and senior high school students, who on normal days use public transport as a public transportation from home to school, at that time made use volunteer service offered by the movement to drive to and pick up them at their schools. The operator who served as the sender of information between the general public with the driver. This activity ran for four days, March 6 to March 9, 2017. This movement shows how the mobilization of movement can be done very quickly using social media Facebook.

The name "Ice Tea Anget" itself appeared spontaneously and without any plan. Ice Teh Anget is a joke for drivers who volunteered in the movement and it is a form intimacy between the volunteers and the public. In the end the nickname Ice Teh Anget became viral among the volunteers so they made the name as the name of the movement.

Studies in social movements cannot be separated by collective identity. In that case the identity built is the identity of the city of Malang through the slogan "Salam Satu Jiwa" (Sasaji). The diversity of the volunteers (they came not only from one particular community but from many communities in Malang City and from various professions) and the identity as "Malang citizen" with the slogan Salam Satu Jiwa further strengthens the unity of movement.

After the public transportation strike, public transportation in Malang was back to normal. Nevertheless the Government of Malang City did not issue specific rules to address the conflict between public transport drivers and application based-taxi drivers and riders. At that time, the steps taken by the City Government of Malang was mediation and spawned an agreement on the zoning ban for online taxis. There are 8 zoning points which are forbidden for online taxis to operate, i.e hotels, malls, houses, stations, markets, entertainment venues, and angkot routes (Aminudin, 2017)

\section{Conclusion}

From the above discussion it can be concluded several things. First social media is the main instrument in the mobilization of social movement in the era of digital society. Second, social activism in Malang City departs from social exclusion of civil society of Malang city. Third, the "Ice Tea Anget" movement is one example of a new social movement that emerged from the concern of online communities based on social issues in Malang. Ice Tea Anget movement became one of the real forms of Facebook social media network became an important instrument in the mobilization of the era in the digital society era.

\section{Reference}

Aminudin, M. (2017). Eight Limits of Online Transport Operate in 
Malang. (online). https://news.detik.co m/berita-jawa-timur/d-3446127/inidelapan-batasan-transportasi-onlineberoperasi-di-malang accessed on 10 November 2017.

Dewantara, RW \& Widhyharto, DS (2015). Activism and Volunteering in the Social Media of Youth Community of Yogyakarta. Journal of Social Science and Political Science. Vol. 19, No. 1 July 2015. pp. 40-52.

Bohang, Fatimah Kartini. 2017. Active Users Facebook approached 2 Billion in Kompas.com

2/2/2017 http://tekno.kompas.com/read/ 2017/02/02/10130037/user.aktif.bulana

n .Facebook.dekati.angka.2.miliar

Indranata, I. (2008). Qualitative Approach for Quality Control. Jakarta: University of Indonesia Press .

Melucci, A. (1996). Challenging Codes: Collective Action in the Information Age. University of Cambridge. Suharko,
2006. New Social Movement Indoensia.Reertoar Farmers Movement. JSP Vol 10 number 1 July 2006. ISSN 1410-4946

Sigap88news.com. Interview with Bambang, activist of Komunitas Peduli Malang, October 2, 2017.

http://www.sigap88news.com/2017/11/02/imr -and-shs-peduli-bersinergi-bersamapolres-malang/

Situmorang, AW (2007). Social Movement: Theory and Practice. Yogyakarta: Student Literature.

Snow DA, Sarah SA, Kriesi, H. (2006). The Blackwell Companion to Social Movements. USA, UK, Australia: Blackwell Publishing.

Suharko, 2006. New Social Movement Indoensia.Reertoar Farmers Movement. JSP Vol 10 number 1 July 2006. ISSN 1410-4946 